ORIGINAL ARTICLE

\title{
Can fertilization and liming affect the amount of litter and roots on Pinus taeda forest floor?
}

\author{
A adubação e a calagem podem afetar a quantidade de liter e raízes na \\ serapilheira de Pinus taeda? \\ Ana Zucon ${ }^{1}$, Rubia Dominschek² (1), Antônio Carlos Vargas Motta ${ }^{1}$ (]) \\ ${ }^{1}$ Departamento de Solos e Engenharia Agrícola, Universidade Federal do Paraná - UFPR, Curitiba, PR, Brasil \\ ${ }^{2}$ Departamento de Produção Vegetal, Universidade Federal do Paraná - UFPR, Curitiba, PR, Brasil
}

\begin{abstract}
How to cite: Zucon, A., Dominschek, R., \& Motta, A. C. V. (2020). Can fertilization and liming affect the amount of litter and roots on Pinus taeda forest floor? Scientia Forestalis, 48(128), e3193.

https://doi.org/10.18671/scifor.v48n128.21
\end{abstract}

\begin{abstract}
The present study evaluated the litter accumulation and the roots contained in the litter as related to different fertilization and liming situations in a commercial stand of Pinus taeda (23 years), after five-year application. The study was established in a site of low fertility, located in the forest region of Jaguariaíva - PR. In 2008 an area of 1 ha was selected to establish a subtraction diagnosis, with 7 treatments (Complete; less macro; less micro; less K; less Zn; less lime and control) with 4 replicates. The accumulated litter dry matter, as well as its compartments was quantified: new litter, old litter and humus. The total dry matter of roots contained in litter $(\leq 2 \mathrm{~mm}$ ) and coarse roots $(>2 \mathrm{~mm})$, total root length, root length (fine and coarse) and total volume of the roots contained in the litter were evaluated. No effect of the treatments on the evaluated attributes was verified, except on the dry matter of old litter. A very expressive accumulation of litter in the stands studied ( 88 to $116 \mathrm{Mg} \mathrm{ha}^{-1}$ ) was verified mostly in the fine fraction ( 58.2 to $83.3 \mathrm{Mg} \mathrm{ha}^{-1}$ ). Dry matter of roots ( 6 to $8.5 \mathrm{Mg} \mathrm{ha}^{-1}$ ) and root length found in litter (142 to 176 thousand $\mathrm{km} \mathrm{ha}^{-1}$ ) were also high, being much higher than those found in the literature. The absence of effect of fertilization and liming on the assessed attributes suggests that these practices are not very efficient in stands with more advanced age.
\end{abstract}

Keywords: Pinus fertilization; Forest site; Decomposition.

\section{Resumo}

O presente trabalho avaliou o acúmulo de serapilheira (liteira) e as raízes contidas na serapilheira em função de diferentes situações de adubação e calagem, de um plantio comercial de Pinus taeda (23 anos), após 5 anos da aplicação. O povoamento estudado foi estabelecido em um sítio de baixo crescimento, situado no polo florestal de Jaguariaíva - PR. Em 2008 uma área de 1 ha foi selecionada para estabelecer estudo de diagnose por subtração, sendo 7 tratamentos (Completo, menos macro, menos micro, menos $\mathrm{K}$, menos Zn, menos calcário e testemunha) com 4 repetições. Foi quantificada a matéria seca de serapilheira acumulada (liter novo, liter velho e liter humificado), além da matéria seca total de raízes contidas na serapilheira, de raízes finas ( $\leq 2 \mathrm{~mm}$ ) e raízes grossas ( $>2 \mathrm{~mm}$ ), o comprimento total das raízes, o comprimento das duas classes de raízes (finas e grossas), e o volume total das raízes contidas na serapilheira. Não foi verificado efeito na grande maioria dos tratamentos sobre os atributos avaliados, exceto sobre a massa de liter velho. Foi verificado um acúmulo muito expressivo de serapilheira no povoamento estudado (88 a $116 \mathrm{Mg} \mathrm{ha}^{-1}$ ), a maior parte de fração fina $(58,21$ a 83,33 $\mathrm{Mg} \mathrm{ha-1}$ ). A matéria seca de raízes ( 6 a 8,5 $\mathrm{Mg} \mathrm{ha}^{-1}$ ) e o comprimento de raízes encontradas na serapilheira (142 a $176 \mathrm{mil} \mathrm{km}$ $\left.\mathrm{ha}^{-1}\right)$, podendo ser considerados bastante elevados. A ausência de efeito da adubação e calagem sobre

Financial support: CNPq project 482519/2011-8.

Conflict of interest: Nothing to declare.

Corresponding author: zuconana@gmail.com

Received: 25 November 2018.

Accepted: 21 November 2019.

Editor: Paulo Henrique Müller Silva.

(c) This is an Open Access article distributed under the terms of the Creative Commons Attribution License, which permits unrestricted use,

c) distribution, and reproduction in any medium, provided the original work is properly cited. 
os atributos avaliados, sugere que estas práticas são pouco eficientes em povoamentos com idade mais avançada.

Palavras-chave: Adubação de Pinus; Sítio florestal; Decomposição.

\section{INTRODUCTION}

Pine plantations are the second forest species planted in Brazil in large areas, occupying 0.72 million hectares. These plantations have been concentrated in the south; the majority in Paraná State with 44\% (Indústria Brasileira de Árvores, 2020). In this state, the Jaguariaíva forest region presented more than 160 thousand hectares of pines, which guarantees the supply of wood for several industries related to this sector in the region (Cardoso, 2013).

Pine plantations in Brazil have been established on poor fertility sites despite of its high national average yield (Moro et al., 2014; Motta et al., 2014; Schumacher et al., 2008). However, some sites in the Jaguariaíva region have been producing low yields and show severe symptoms of nutritional deficiency (Batista, 2011). The occurrence of deficiency symptoms was very significant since pine is considered to be of low nutritional demand (Motta et al., 2014). However, not only the poor fertility of the soil is responsible for the occurrence of lack of nutrients; nutrient exhaustion by successive forest harvesting cycles without nutrient reposition may have large impacts as well (Berthrong et al., 2009).

The forest planted under low fertility sites has been shown to have a larger accumulation of litter on soil when compared to high fertility ones (Motta et al., 2014). Hence, it is possible that the lack of nutrients could be responsible for litter accumulation and consequently fertilization and liming could even diminish litter accumulation. However, nutrients and lime application has been shown to have a different effect on litter accumulation; varying from a large decrease (Jandl et al., 2003) to no effect (Moro et al., 2014); and an increase of the amount (Dames et al., 1998). There is a gap of information about this in Brazilian pine plantations.

Furthermore, it is known that roots play a significant role to explain physiologic processes, especially when related to mineral nutrition and water availability in trees (Lopes et al., 2010). On one hand, litter accumulation on the forest floor provides a new environment for root exploration seeking nutrients and water. This may work as a short cut to nutrient cycling, since the root is able to take up the nutrients right after their release from residues and before they reach the soil. There is an indication that it can be a great contribution to nutrient uptake from litter (Motta et al., 2014). On the other hand, the amount of roots within the litter layer can be influenced by plant nutrition (Sayer et al., 2006); and application of $\mathrm{K}$ has resulted in a decrease of the amounts of root under native forests (Sayer et al., 2012; Yavitt et al., 2011). In addition, a planted forest with increased nutrient supply resulted in lower fine root length density for litter and soil surface; but the opposite was observed for specific root density (Bakker et al., 2009).

Bakker (1999) also observed that the effect of moderate amounts of lime (1.4 to $2.8 \mathrm{Mg}$ $\mathrm{ha}^{-1} \mathrm{CaCO}_{3}$ ) application on oak root growth lasted for 10 to 25 years; suggesting a long-term effect. Shepard \& Mitchell (1990) also reported the effects of K application after 40 years of application on growth and plant biomass. They associated it to the effective $\mathrm{K}$ cycling in litterfall. Again, there are few studies on the quantification of roots in litter layers from pine plantations (Lopes et al., 2010; Motta et al., 2014) in Brazil. There are also no studies on the effect of fertilization and liming on pine root growth within litter layers.

Therefore, the aim of this study was to analyze the effect of different fertilization and liming conditions on the dry matter of accumulated litter and on the roots contained in it. The experiment was performed in the Jaguariaíva - PR forest region, on a poor soil site. 


\section{MATERIAL AND METHODS}

\section{Site description}

The experiment was conducted in the municipality of Jaguariaíva, Northeast Region of the State of Paraná, Brazil. According to Köppen, the region climate varies from subtropical (Cfa) and temperate $(\mathrm{Cfb})$, with an average annual rainfall and temperature around $1,480 \mathrm{~mm}$ and $19^{\circ} \mathrm{C}$, respectively. Frosts may occur in the region and there is a decreased precipitation in the winter months (Batista, 2011).

The soil derives from sandstones, belonging to the geological formation Itararé and Furnas. According to the Brazilian Soil Taxonomy, it was classified as Cambissolo Latossólico, with medium to sandy texture. The soil chemical characterization was done by sampling in each experiment block at three depths $(0-20,20-40$ and 40-60 cm) with auger. Twenty subsamples were collected in each block to form a compost sample. The soil samples were analyzed (Table 1) for $\mathrm{pH} \mathrm{CaCl} 2$ 0,01 M (1:2,5 soil: solution ratio); exchangeable $\mathrm{Al}, \mathrm{Ca}$ and $\mathrm{Mg}$ extracted by $\mathrm{KCl} 1 \mathrm{M}$, available $\mathrm{K}$ and $\mathrm{P}$ extracted by Mehlich I, organic $\mathrm{C}$ by chemical oxidation by dichromate and $(\mathrm{H}+\mathrm{Al})$ by calcium acetate $0,5 \mathrm{M}$ at $\mathrm{pH}$ 7.0.

Table 1. Soil chemical properties of the study area before fertilization and liming - Jaguariaíva - Paraná State.

\begin{tabular}{|c|c|c|c|c|c|c|c|c|c|c|c|}
\hline \multirow[t]{2}{*}{ Depth } & $\begin{array}{c}\mathrm{pH} \\
\mathrm{CaCl}_{2}\end{array}$ & Al & $\begin{array}{c}\mathrm{H}+ \\
\mathrm{Al}\end{array}$ & $\mathrm{Ca}$ & $\mathrm{Mg}$ & K & $\begin{array}{c}\text { CEC }^{*} \\
\text { pH 7,0 }\end{array}$ & $\mathbf{P}$ & C & $\mathrm{m} \%$ & V \% \\
\hline & \multicolumn{2}{|c|}{$0.01 \mathrm{M}$} & \multicolumn{3}{|c|}{$\mathrm{cmol}_{\mathrm{c}} \mathrm{dm}^{-3}$} & $\mathrm{mg} \mathrm{dm}$ & & \multicolumn{4}{|c|}{$\mathrm{g} \mathrm{dm}^{-3}$} \\
\hline $0-20$ & 4,0 & 1,5 & 7,2 & 0,1 & 0,1 & 0,03 & 7,5 & 0,7 & 20,3 & 86 & 3,3 \\
\hline $20-40$ & 4,1 & 1,1 & 6,0 & 0,1 & 0,1 & 0,02 & 6,2 & 0,6 & 15,3 & 84 & 3,4 \\
\hline $40-60$ & 4,1 & 0,9 & 5,9 & 0,1 & 0,1 & 0,02 & 6,1 & 0,2 & 15,5 & 81 & 3,5 \\
\hline
\end{tabular}

${ }^{*} \mathrm{CEC}=$ cation exchangeable capacity; $\mathrm{m}=$ aluminum saturation of effective $\mathrm{CEC} ; \mathrm{V}=$ base saturation of the $\mathrm{CEC}$ a $\mathrm{pH} 7$.

\section{Experimental design}

An omission type experiment or diagnosis for subtraction was used with seven treatments in order to evaluate the limiting factor to yield at 18 years of age from a commercial forest plantation. The experimental design was randomized blocks, with four replicates (blocks). The seedlings were planted with three meters spacing between rows and two-meter spacing between plants $(3 \mathrm{~m} \times 2 \mathrm{~m})$. The plot had 64 trees, eight lines each with eight plants, in an area of $384 \mathrm{~m}^{2}$. The evaluated area was composed by 16 trees centrally located $(4 \times 4)$ with two border rows separating plots.

The experimental was established in 2008; an area of 1.5 hectare was selected with the application of the following treatments:

- Treatment 1: Complete treatment: application of all nutrients (N, P, K, Zn, Cu, B, Mo, Ca + Mg in the dolomitic limestone form);

- Treatment 2: Complete treatment minus macronutrients: application of all nutrients with macronutrients $(\mathrm{N}, \mathrm{P}, \mathrm{K})$ omission;

- Treatment 3: Complete treatment minus micronutrients: application of all nutrients with micronutrients ( $\mathrm{Zn}, \mathrm{Cu}, \mathrm{B}, \mathrm{Mo})$ omission;

- Treatment 4: Complete treatment minus K: application of all nutrients with potassium (K) omission;

- Treatment 5: Complete treatment minus Zn: application of all nutrients with zinc (Zn) omission;

- Treatment 6: Complete treatment minus liming: application of all nutrients with limestone (Ca + Mg) omission;

- Treatment 7: Control treatment: control, absence of fertilization and liming.

The amount of fertilizer applied in 2008 in the different treatments, referring to 1 hectare,

were: $40 \mathrm{~kg}$ of nitrogen (89 kg of urea, $45 \%$ of $\mathrm{N}$ ), $60 \mathrm{~kg}$ of $\mathrm{P}_{2} \mathrm{O}_{5}(146 \mathrm{~kg}$ of triple 
superphosphate, $41 \%$ of $\mathrm{P}_{2} \mathrm{O}_{5}$ ), $80 \mathrm{~kg}$ of $\mathrm{K}_{2} \mathrm{O}\left(133 \mathrm{~kg}\right.$ of $\mathrm{KCl}, 60 \%$ of $\mathrm{K}_{2} \mathrm{O}$ ), $3 \mathrm{~kg}$ of zinc ( $20 \mathrm{~kg}$ of $\mathrm{ZnSO}_{4}, 15 \%$ of $\mathrm{Zn}$ ), $2 \mathrm{~kg}$ of boron (20 kg of ulexite, $10 \%$ of B), $2 \mathrm{~kg}$ of copper ( $8.3 \mathrm{~kg} \mathrm{CuSO}, 24 \%$ $\mathrm{Cu}$ ), $20 \mathrm{~g}$ of molybdenum ( $61 \mathrm{~g}$ of $\mathrm{Na}_{2} \mathrm{MoO}_{4}, 39 \%$ of $\mathrm{Mo}$ ) and 1.3 tons of dolomitic limestone.

The different sources of fertilizers were weighed in the laboratory, brought to the field where they were mixed and applied manually by broadcasting over the litter layer. The lime was applied just after fertilizer application in the same manner.

\section{Sampling and processing of samples}

The litter sampling was carried out in 2013 , by collecting four samples in each plot. A frame with $10 \times 10 \mathrm{~cm}$ was placed and pressed against the litter surface. Then, the litter layers were cut with knife and the outside litter part was removed. The litter monolith was gently removed and brought to the lab. This litter was divided into new litter (NL), old litter (OL) and fragmented humus litter (FHL); separated in the field and kept in a $4^{\circ} \mathrm{C}$ refrigerator until analysis.

The NL and OL were separated into needles, residues (other tissues such as reproductive structures and branches) and roots, when present. The roots from FHL were manually separated using tweezers. Mycorrhizae were taken with the roots. These roots were then separated in coarse and fine roots, using a standard root as a parameter, with a threshold of $1 \mathrm{~mm}$. Using a scanner (Epson Expression 11000XL), they were analyzed in WinRhizo Pro 2013 A software with which it was possible to determine the diameter, length and volume of roots.

After root separation, the FHL was sieved through a $2 \mathrm{~mm}$ sieve, dividing it into two fractions: fine $(<2 \mathrm{~mm})$ and coarse $(>2 \mathrm{~mm})$. All other separated materials from $\mathrm{NL}, \mathrm{OL}$ e $\mathrm{FHL}$ were dried in the greenhouse at $65^{\circ} \mathrm{C}$ until constant mass, and then weighed.

The information was extrapolated to the area, obtaining the dry matter of fine roots $(\leq 2$ $\mathrm{mm}$ diameter), dry matter of coarse roots ( $>2 \mathrm{~mm}$ diameter), the total length of roots, length of fine roots, length of coarse roots and total root volume of each sample by hectare.

\section{Statistical analysis}

The data was analyzed using the analysis of variance with $5 \%$ significance. The assumptions of normality and homogeneity of variance was verified. In case of no normality, variables were transformed. Tukey's test was applied in case of significant difference among data. The statistical analysis was performed on software R (version 3.4.4).

\section{RESULTS AND DISCUSSION}

\section{Total, new, old and humus litter}

The total litter dry matter (DM) varied from 88 to $116 \mathrm{Mg} \mathrm{ha}^{-1}$ (Figure 1), considering the three fractions NL, OL and FHL. The obtained values of total litter dry matter values can be considered as high, compared to 9 to $26 \mathrm{Mg} \mathrm{ha}^{-1}$ found for Pinus spp stands in different ages Rio Grande do Sul (Kleinpaul et al., 2003; Konig et al., 2003) and Paraná state (Watzlawick \& Caldeira, 2004). However, Schneider (2011) and Bizon (2005) working in the region of our experiment site found from 55 to 78 and 20 to $91 \mathrm{Mg} \mathrm{ha}^{-1}$ of total litter, respectively. These results confirmed the high potential of litter accumulation in the region. Additionally, the low soil fertility in the region, also confirmed the possible inverse relationship between soil fertility and amount of litter on the forest floor (Motta et al., 2014). The age of the plantation can also contribute since there is a direct relationship between age and the amount of litter on the forest floor (Haag, 1985; Moro et al., 2014; Viera et al., 2014).

These results reinforce the idea that litter plays an important role for the productivity maintenance in Pinus stands on low fertility soils; especially so in stands of later age in which the underlying soil layers have already been depleted (Vogel et al., 2004; Piovesan et al., 2012). 


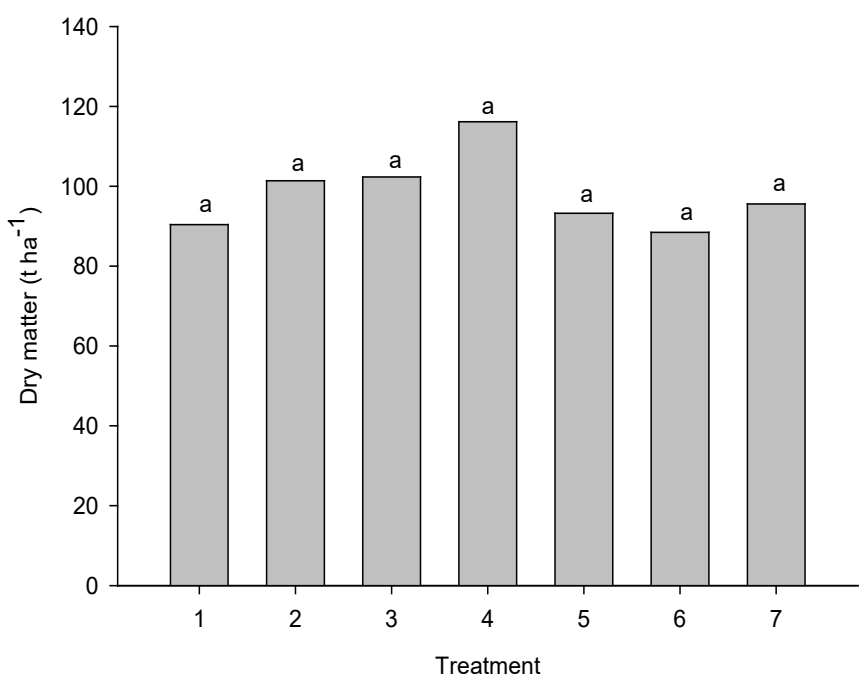

Figura 1. Litter total dry matter from a stand of Pinus taeda with 23 years old after 5 years of experiment with fertilization and liming in different treatments - Jaguariaíva - Paraná State - Brazil.

The humus litter corresponds to the major layer of the litter, with average values between 74 and $104 \mathrm{Mg} \mathrm{ha}^{-1}$ (Figure 2). This fraction represents $86 \%$ of the total litter dry matter, which comprises most of the root dry matter found in this experiment. The fine and coarse fractions of humus litter varied from 58.2 and $83.3 \mathrm{Mg} \mathrm{ha}^{-1}$ for the fine fraction and 12.7 and $20.7 \mathrm{Mg}$ ha $^{-1}$ for the coarse fraction (Figure 3). It may be explained by the advanced decomposition stage this part is in, favoring the occurrence of roots. From the results, an average proportion of 4:1 (fine/coarse) could be estimated, indicating that most of the humus litter is composed by fine materials. The variation coefficient (VC) estimated for this proportion was $17,8 \%$, since the distribution of the values obtained from this proportion varied between 6:1 and 2.5:1, considering that there was a high variability in the coarse fraction values.

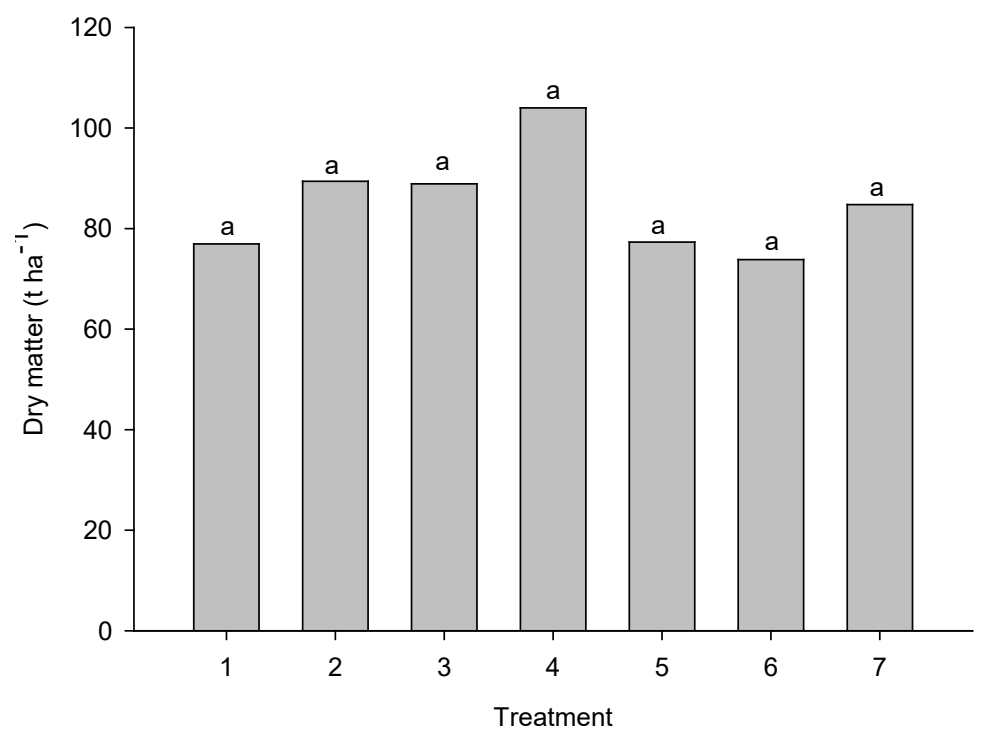

Figura 2. Humus litter dry matter from a stand of Pinus taeda with 23 years old after 5 years of experiment with fertilization and liming in different treatments - Jaguariaíva - Paraná State - Brazil. 

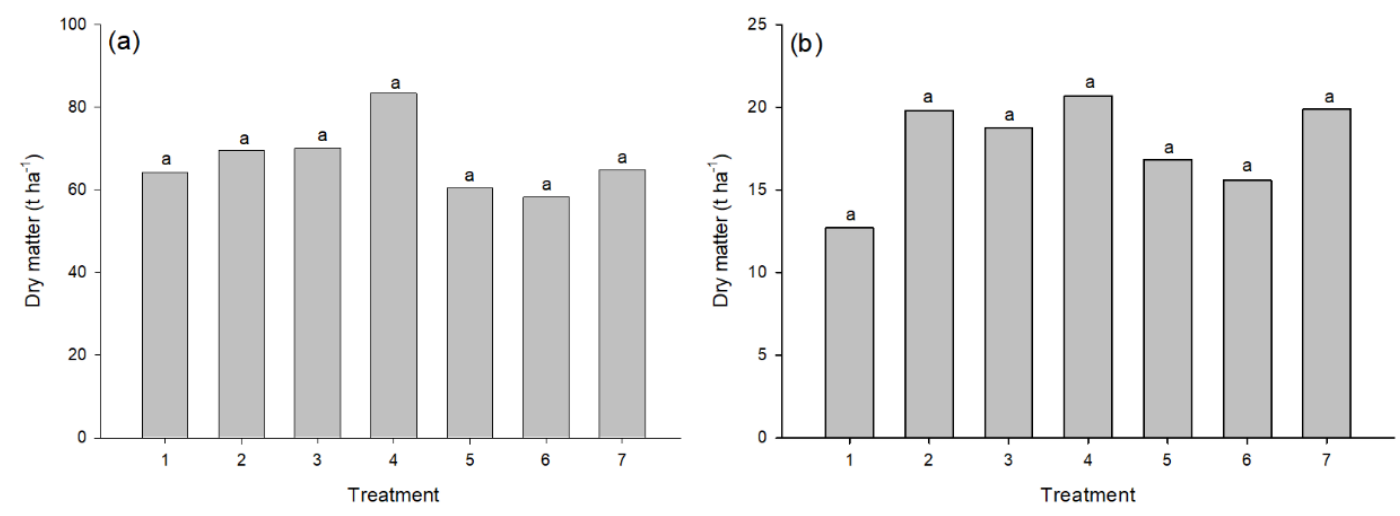

Figura 3. Fine fraction dry mass (a) and coarse fraction dry mass (b) of humus litter from a stand of Pinus taeda with 23 years old after 5 years of experiment with fertilization and liming in different treatments - Jaguariaíva - Paraná State.

The new litter and the old litter fractions were 3.9 to $4.8 \mathrm{Mg} \mathrm{ha}^{-1}$ and 6.7 to $11.4 \mathrm{Mg} \mathrm{ha}^{-1}$ on average, respectively (Figure 4). Mainly needles composed the new litter (no shown data). In the old litter it was possible to identify other components, such as productivity structures, fine branches and needles (no shown data). However, needles still made up the main compartment, corresponding to $82.7 \%$ of the total dry matter in old litter. The variation coefficient for this attribute was low, since the percentage of needles in old litter varied in average from 79.8 to $86.9 \%$. Thus, the data indicate that there is a pattern of the needle proportion and residues in the old litter.
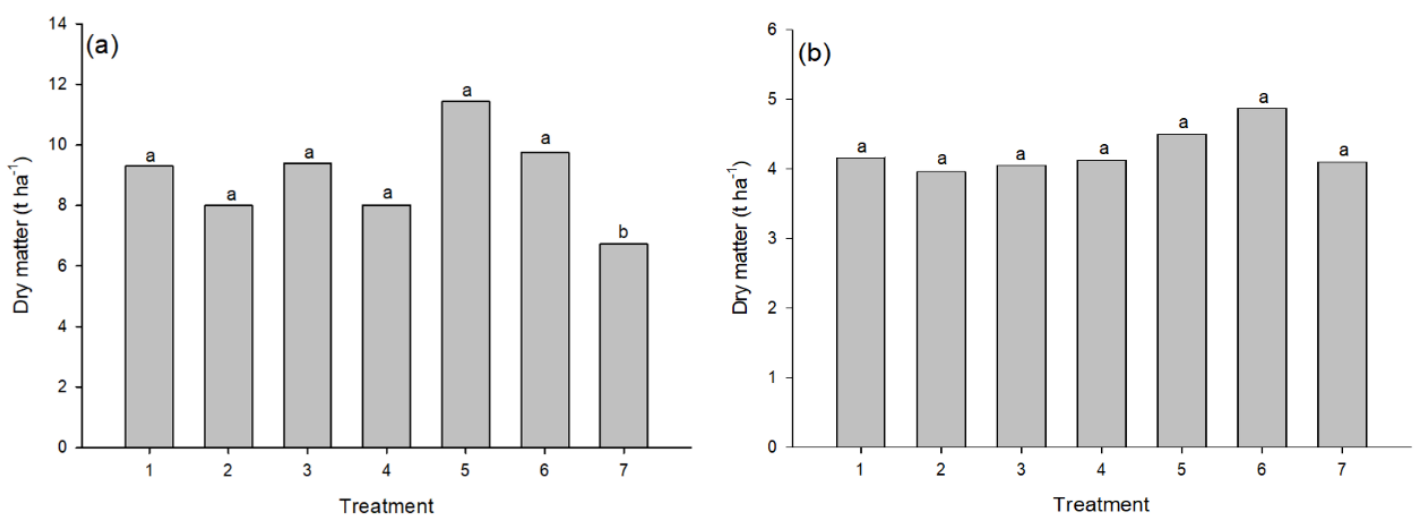

Figura 4. Old litter dry mass (a) and new litter dry mass (b) per hectare from a stand of Pinus taeda with 23 years old after 5 years of experiment with fertilization and liming in different treatments Jaguariaíva - Paraná State - Brazil.

There was no difference between treatments, except for treatment 7 (control), which clearly indicates that the site is indeed poor, and the fertilization and liming had an effect to increase the FOL content. Also, there is a trend for higher amount of litter on $\mathrm{K}$ omission. Early senescence of needles was pointed out as an adaptation to lack of potassium in Pinus pinaster stands, with an increase of material deposition (Eimil et al., 2015). Viera \& Schumacher (2010) also found that the content of $\mathrm{N}$ and $\mathrm{K}$ relate negatively with the litter amount in a Pinus forest. Residue input, its decomposition rate and rate of humus formation have been responsible for the three major factors that control the amount of litter on the forest floor. Thus, it is possible to infer that on highly productive sites litter decomposition is faster, and in less productive sites the litter layer is thicker (Viera et al., 2014), which could not be found in this experiment.

On the other hand, it can be also inferred that with nutrient input from fertilizers and lime, there would be an increase of dry matter production of litter, but this has not occurred. 
Therefore, it seems that fertilization and liming application did not change this balance. In addition, there was indication of a lower input of residue in the control than other treatments, since it yielded the smallest value for the new and old litter fraction. Therefore, it is possible that the increase on decomposition rate with fertilization and liming compensates for the input.

\section{Root matter}

The total amount of roots present in the litter varied in average from 6.4 to $8.5 \mathrm{Mg}$ $\mathrm{ha}^{-1}$, as shown in Figure 5 . The fertilization and liming did not affect the dry matter amount of roots within the litter layer, except for treatment 5. Somehow, the omission of $\mathrm{Zn}$ caused a significant reduction in the roots found in the litter. It can indicate that this nutrient was already a limiting nutrient in the poor fertility soil, since its omission affected the root growth negatively. No explanation could be drawn to elucidate this effect, since no information in the literature was found describing this root biomass reduction. Thus, morpho-physiological studies would be needed in order to understand this effect properly.

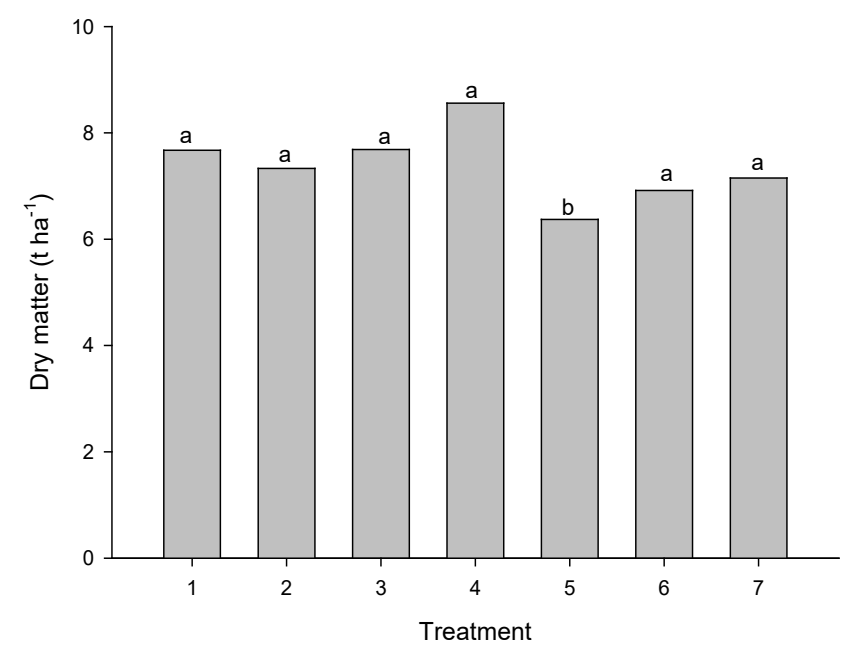

Figura 5. Total dry mass of roots contained in the litter per hectare from a stand of Pinus taeda with 23 years old after 5 years of experiment with fertilization and liming in different treatments - Jaguariaíva Paraná State - Brazil. Different letters indicate significant difference between treatments (Tukey test, $\mathrm{P}<0.05)$

The amount of fine roots contained in the litter was high (Figure 6) and varied from 6.4 to $8.6 \mathrm{t} \mathrm{ha}^{-1}$ in average; since other research done in Pinus stands by Vogel et al. (2004), Lopes et al. (2010) and Selle et al. (2010) have shown fine root values with $3.5 \mathrm{Mg} \mathrm{ha}^{-1}$ at a maximum, considering whole soil profile. The coarse root matter presented a high variation in values: from 3 to $17 \mathrm{~kg} \mathrm{ha}^{-1}$ on average. So, the amount of coarse roots was insignificant compared to fine roots in the litter layer.

The high occurrence of fine roots in litter of Pinus can be related to the role of this layer in the recycling processes, provision of nutrients and water, especially under limiting conditions (Motta et al., 2014; Lopes et al., 2010). A strict relation between the litter and fine roots was observed, since the stand is on a poor nutrient soil; acid and with medium texture, which indicates a low water retention capacity. Thus, in order to overcome the low nutrient supply, the roots concentrate in the litter, which may function as an expressive source of nutrients, creating better conditions for root development (Motta et al., 2014).

On the other hand, Sayer et al. (2006) studying the relationship between roots and litter in a tropical forest, found high biomass content of fine roots in litter freshly added to the soil, 
$202 \mathrm{~kg} \mathrm{ha}^{-1}$. The author states that despite seasonal influence, the amount of fine roots also varied with the content of fresh litter added to the soil, indicating a strong relationship between nutrient release during litter decay and fine root growth. Thus, this relationship suggests that root proliferation occurs in response to the more easily obtainable nutrients in the litter, rather than an adaptation to soil fertility.
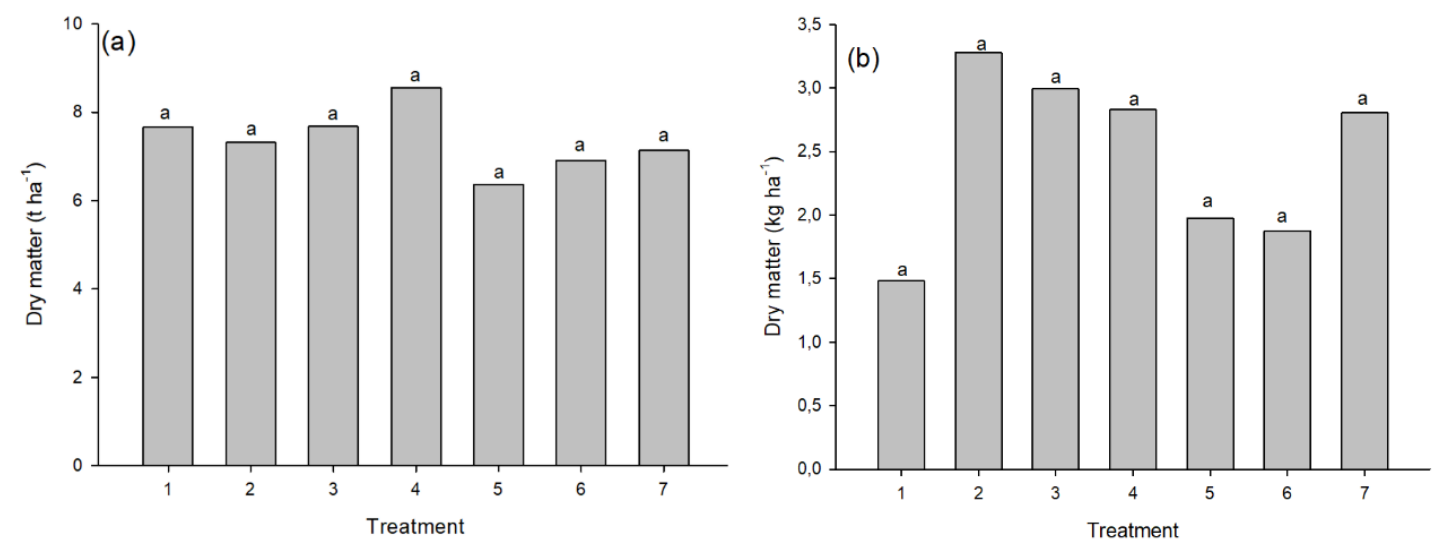

Figura 6. Fine fraction dry mass (a) and coarse fraction dry mass (b) of litter per hectare from a stand of Pinus taeda with 23 years old after 5 years of experiment with fertilization and liming in different treatments - Jaguariaíva - Paraná State.

It is also possible that potassium is highly related to root proliferation. Figure 6 may support this hypothesis, where in the treatment with $\mathrm{K}$ omission, there was a higher presence of roots. It suggests that $\mathrm{K}$ is potentially a limiting factor on these sites. Following the same logic Sayer et al. (2012), studying the nutrient cycling in tropical forest found that fine roots were lower in added $\mathrm{K}$ sites, which indicates that with a higher supply of nutrients, the fine root biomass is decreased, so the plant allocates its energy to another compartment for growth. Using K, Yavitt et al. (2011) also found a lower root biomass in the soil of a tropical forest in Panama, in 4 years evaluations.

Under temperate conditions, Bakker et al. (2009) also found that the addition of nutrients $(\mathrm{N}, \mathrm{P}, \mathrm{K}, \mathrm{Ca}$, and $\mathrm{Mg}$ ) decreased the $P$. pinaster root density in both litter and soil. On the other hand, Albaugh et al. (1998) found less biomass production under fertilization treatments, which they associated as being a result of greater allocation of metabolics to the foliage (photosynthesizing tissue) over to fine roots. Although it describes the opposite effect of this study, the morpho-physiological concept described by the author may explain the effect found in this study. This may suggest that the plants had allocated more biomass to their fine roots over the foliage tissue under lack of potassium conditions in order to enhance the area exploited by the roots in search of more resources.

\section{Root length}

Total length of roots present in the litter varied in average from 142 to 176 thousand $\mathrm{km}$ ha-1 ${ }^{-1}$ as shown in Figure 7.

The coarse root length in the litter had a high variation in the estimated values between 25 and $123 \mathrm{~km} \mathrm{ha}^{-1}$, shown in Figure 8 . The coefficient of variation estimated was also very high (118.9\%). 


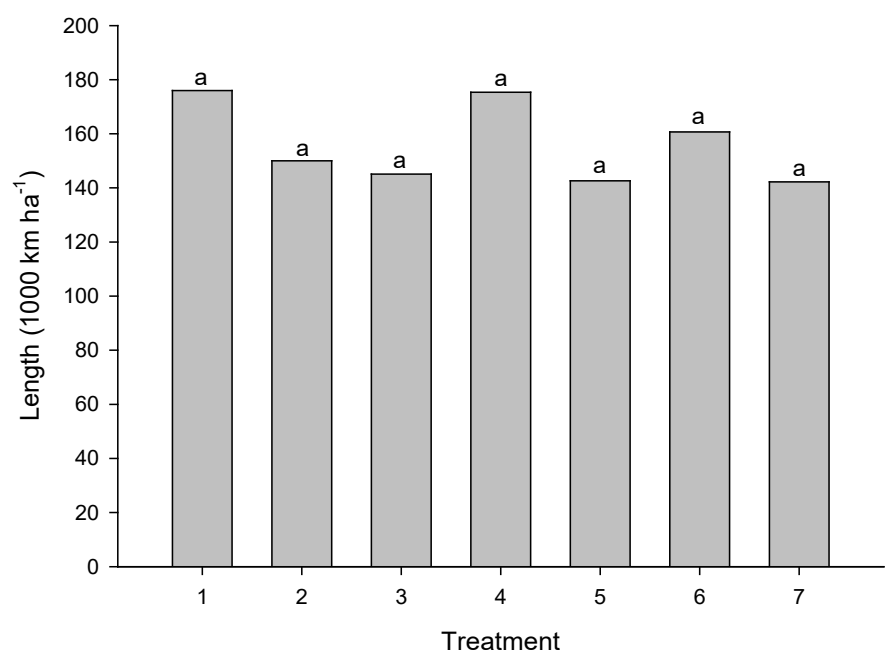

Figura 7. Total length of roots contained in the litter per hectare from a stand of Pinus taeda with 23 years old after 5 years of experiment with fertilization and liming in different treatments - Jaguariaíva Paraná State.
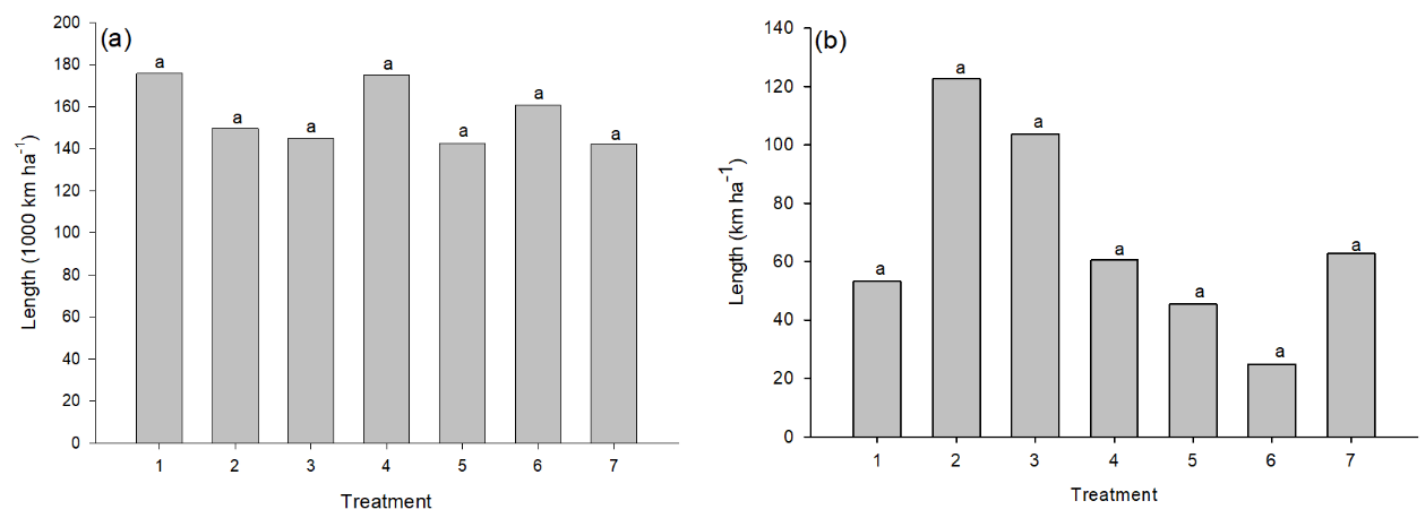

Figura 8. Length of fine roots (a) and coarse roots (b) contained in the litter per hectare from a stand of Pinus taeda with 23 years old after 5 years of experiment with fertilization and liming in different treatments - Jaguariaíva - Paraná State.

Possibly there was no statistic difference among treatment, due to the same reason as for dry matter of fine roots, since there is a similar behavior of dry matter and length of roots. The high values for the length of roots in the litter can be explained by Gonçalves \& Mello (2004), in which the trees tend to produce longer roots in order to explore higher volume of soil, especially under conditions with low availability of water and nutrients. On the other hand, it would also be possible to expect that root length was reduced because roots need less length to locate nutrients in a fertile soil (Yavitt et al., 2011). This was not the case in this study, as explained before; since the fertilization was applied in later ages and the roots had already developed in the low nutrient environment, which did not reflect any differences.

\section{Root volume}

It was estimated that the values for root volume in the litter, varied in average from 25.1 to $31.8 \mathrm{~m}^{3} \mathrm{ha}^{-1}$ (Figure 9). There was not significant difference among treatments, since the volume of roots is related to the diameter and the total length in the litter. 


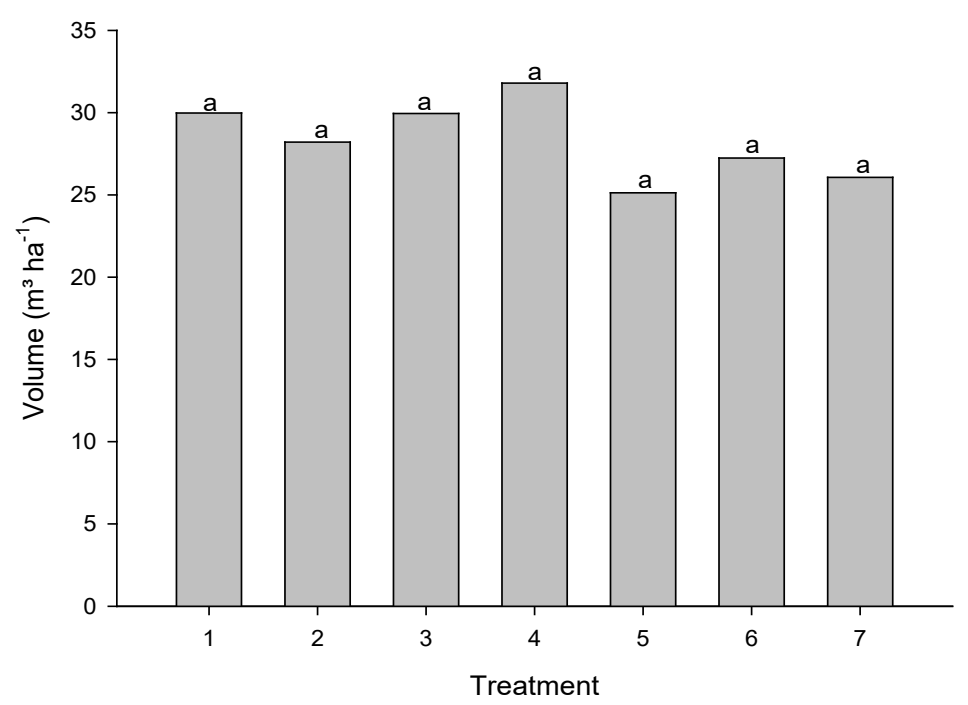

Figura 9. Total length of roots contained in the litter per hectare from a stand of Pinus taeda with 23 years old after 5 years of experiment with fertilization and liming in different treatments - Jaguariaíva Paraná State.

If we consider that practically all root dry matter was contained in the humus litter, and it had in average $8 \mathrm{~cm}$ of depth in the stand; we would have an equivalent volume of humus litter of $800 \mathrm{~m}^{3} \mathrm{ha}^{-1}$. Based on this, it is possible to calculate that the roots present in the occupied area, accounted in average for 3 to $4 \%$ of the volume occupied by the FHL.

The data of this experiment confirms the idea that litter may play an important role for nutrient cycling, water and nutrient absorption in stands of Pinus taeda L. established in poor sites.

\section{CONCLUSION}

The expressive quantity of litter in the studied area confirms the accumulation of litter in sites with low fertility soils. A high content of dry matter and length of roots in the litter was also observed. This may indicate that the litter under low soil fertility stimulates the growth of roots in the litter in order to absorb the nutrients present in the residues.

For the period evaluated no effect from fertilization and liming in the stand was verified, indicating that this management procedure is not efficient in later age stands of Pinus.

\section{AGRADECIMENTOS}

The authors thank Vale do Corisco and Valor Florestal Companies for the field work support and staff (Renato Teixeira Lima, Antônio - Mineiro, Felipe Mazurki Perucio) and Maria Emilia Kudla from UFPR by support on root evaluation. ACVM is grateful to National Council for Scientific and Technological Development (CNPq) for the financial support and Coordination for the Improvement of Higher Education Personnel (CAPES) for the financial support (scholarships)

\section{REFERENCES}

Albaugh, T. J., Allen, H. L., Dougherty, P. M., Kress, L. W., \& King, J. S. (1998). Leaf area and above-and belowground growth responses of loblolly pine to nutrient and water additions. Forest Science, 44(2), 317-328.

Bakker, M. R. (1999). Fine-root parameters as indicators of sustainability of forest ecosystems. Forest Ecology and Management, 122(1-2), 7-16. http://dx.doi.org/10.1016/S0378-1127(99)00028-6.

Bakker, M. R., Jolicoeur, E., Trichet, P., Augusto, L., Plassard, C., Guinberteau, J., \& Loustau, D. (2009). Adaptation of fine roots to annual fertilization and irrigation in a 13-year-old Pinus pinaster stand. Tree Physiology, 29(2), 229-238. PMid:19203948. http://dx.doi.org/10.1093/treephys/tpn020. 
Batista, A. H. (2011). Influência da calagem e adubação na acidez do solo e ciclagem de $\mathrm{K}^{+}, \mathrm{Ca}^{2+}$ e $\mathrm{Mg}^{2+}$ em plantios de Pinus taeda L. no pólo florestal de Jaguariaíva - PR (Dissertação de mestrado). Setor de Ciências Agrárias, Universidade Federal do Paraná, Curitiba.

Berthrong, S. T., Jobbágy, E. G., \& Jackson, R. B. (2009). A global meta-analysis of soil exchangeable cations, pH, carbon, and nitrogen with afforestation. Ecological Applications, 19(8), 2228-2241. PMid:20014590. http://dx.doi.org/10.1890/08-1730.1.

Bizon, J. M. C. (2005). Avaliação da sustentabilidade nutricional de plantios de Pinus taeda L. usando um balanço de entrada-saída de nutrientes (Dissertação de mestrado). Escola Superior de Agricultura "Luiz de Queiroz", Universidade de São Paulo, Piracicaba.

Cardoso, P. (2013). Jaguariaíva no Paraná tem a mais completa cadeia produtiva existente no país. Campo Grande: Painel Florestal.

Dames, J. F., Scholes, M. C., \& Straker, C. J. (1998). Litter production and accumulation in Pinus patula plantations of the Mpumalanga Province, South Africa. Plant and Soil, 203(2), 183-190. http://dx.doi.org/10.1023/A:1004346025926.

Eimil, F. C., Sánchez, R. F., Álvarez, R. E., \& Rodríguez, S. R. (2015). Variability in needle lifespan and foliar biomass along a gradient of soil fertility in maritime pine plantations on acid soils rich in organic matter. Forest Ecology and Management, 343, 34-41. http://dx.doi.org/10.1016/j.foreco.2015.01.030.

Gonçalves, J. L. M., \& Mello, S. L. M. (2004). The root system of trees. In J. L. M. Gonçalves \& V. Benedetti (Eds.), Forest nutritionandfertilization (pp. 223-270). Piracicaba: IPEF.

Haag, H. P. (1985). Ciclagem de nutrientes em florestas tropicais. Campinas: Fundação Cargill.

Indústria Brasileira de Árvores - IBÁ. (2020). Relatório IBÁ 2020. São Paulo: IBÁ.

Jandl, R., Kopeszki, H., Bruckner, A., \& Hager, H. (2003). Forest soil chemistry and mesofauna 20 years after an amelioration fertilization. Restoration Ecology, 11(2), 239-246. http://dx.doi.org/10.1046/j.1526-100X.2003.00179.x.

Kleinpaul, I. S., Schumacher, M. V., König, F. G., \& Kleinpaul, J. J. (2003). Acúmulo de serapilheira em povoamentos de Pinus e Eucaliptos no Campus da UFSM. In Anais do Congresso Florestal Estadual do Rio Grande do Sul. Nova Prata: Prefeitura Municipal.

Konig, F. G., Schumacher, M. V., Brun, E. J., Kleinpaul, I. S., Kleinpaul, J. J., \& Bonamigo, A. (2003). Acúmulo de serapilheira sobre o solo em uma rotação de Pinus taeda no município de Cambará do Sul. In Anais do $9^{\circ}$ Congresso Florestal Estadual do Rio Grande do Sul. Nova Prata: Prefeitura Municipal.

Lopes, V. G., Schumacher, M. V., Calil, F. N., Viera, M., \& Witschoreck, R. (2010). Quantificação de raízes finas em um povoamento de Pinus taeda L. e uma área de campo em Cambará do Sul, RS. Ciência Florestal, 20(4), 569-578. http://dx.doi.org/10.5902/198050982415.

Moro, L., Gatiboni, L. C., Simonete, M. A., Cassol, P. C., \& Chaves, D. M. (2014). Resposta de Pinus taeda com diferentes idades à adubação NPK no Planalto Sul Catarinense. Revista Brasileira de Ciência do Solo, 38(4), 1181-1189. http://dx.doi.org/10.1590/S0100-06832014000400014.

Motta, A. C. V., Barbosa, J. Z., Consalter, R., \& Reissmann, C. B. (2014). Nutrição e adubação da cultura de Pinus. In R. M. Prado \& P. G. S. Wadt (Eds.), Nutrição e adubação de espécies florestais e palmeiras (pp. 383-426). Jaboticabal: FUNEP.

Piovesan, G., Schumacher, M. V., Viera, M., Lopes, V. G., \& Welter, C. (2012). Deposição de serapilheira em povoamentos de pinus. Pesquisa Agropecuária Tropical, 42(2), 206-211. http://dx.doi.org/10.1590/S1983-40632012000200012.

Sayer, E. J., Joseph Wright, S., Tanner, E. V. J., Yavitt, J. B., Harms, K. E., Powers, J. S., Kaspari, M., Garcia, M. N., \& Turner, B. L. (2012). Variable responses of lowland tropical forest nutrient status to fertilization and litter manipulation. Ecosystems, 15(3), 387-400. http://dx.doi.org/10.1007/s10021011-9516-9.

Sayer, E. J., Tanner, E., \& Cheesman, A. W. (2006). Increased litterfall changes fine root distribution in a moist tropical forest. Plant and Soil, 281(1-2), 5-13. http://dx.doi.org/10.1007/s11104-005-6334-x.

Schneider, T. (2011). Crescimento e teores de B, Cu, Mn, Fe e Zn em Pinus taeda L., como resultado da adubação e calagem sob técnica da omissão de nutrientes (Dissertação de mestrado). Setor de Ciências Agrárias, Universidade Federal do Paraná, Curitiba.

Schumacher, M. V., Viera, M., \& Witschoreck, R. (2008). Produção de serapilheira e transferência de nutrientes em área de segunda rotação com floresta de Pinus taeda L. no município de Cambará do Sul, RS. Ciência Florestal, 18(4), 471-480. http://dx.doi.org/10.5902/19805098431.

Selle, G. L., Vuaden, E., Murari, A. B., Hack, C., Farias, J. A., \& Thoma, R. (2010). Biomassa radicular, densidade do solo e análise química do solo de um povoamento de Pinus sp. Ambiência, 6(1), 61-74. 
Shepard, J. P., \& Mitchell, M. J. (1990). Nutrient cycling in a red pine plantation thirty-nine years after potassium fertilization. Soil Science Society of America Journal, 54(5), 1433-1440. http://dx.doi.org/10.2136/sssaj1990.03615995005400050037x.

Viera M, Schumacher MV. Variação mensal da deposição de serapilheira em povoamento de Pinus taeda L. em área de campo nativo em Cambará do Sul - RS. Rev Arvore. 2010;34(3):487-94. http://dx.doi.org/10.1590/S0100-67622010000300012.

Viera, M., Schumacher, M. V., Araújo, E. F., Corrêa, R. S., \& Caldeira, M. V. W. (2014). Deposição de serapilheira e nutrientes em plantio de Eucalyptus urophyllax E. globulus. Floresta e Ambiente, 21(3), 327-338. http://dx.doi.org/10.1590/2179-8087.053913.

Vogel, H. L. M., Schumacher, M. V., Witschoreck, R., Calil, F. N., \& Pissinin, L. Z. (2004). Biomass and length of fine roots in Pinus taeda L. in South Brazil. In Eurosoil (10 p.). Freiburg.

Watzlawick, L. F., \& Caldeira, M. V. W. (2004). Estimativa de biomassa e carbono orgânico em povoamentos de Pinus taeda L. com diferentes idades. Biomassa \& Energia, 1(4), 371-380.

Yavitt, J. B., Harms, K. E., Garcia, M. N., Mirabello, M. J., \& Wright, S. J. (2011). Soil fertility and fine root dynamics in response to 4 years of nutrient $(\mathrm{N}, \mathrm{P}, \mathrm{K})$ fertilization in a lowland tropical moist forest, Panama. Austral Ecology, 36(4), 433-445. http://dx.doi.org/10.1111/j.1442-9993.2010.02157.x.

Authors' contributions: AZ: data curation, writing - original draft, writing - review \& editing, investigation, visualization, RD: data curation, writing - original draft, methodology, formal Analysis, AM: conceptualization, project administration, resources, supervision, validation. 